\title{
Protestant Christianity and Civil Society in Authoritarian China
}

The Impact of Official Churches and Unregistered "Urban Churches" on Civil Society Development in China in the 2000s

\section{Carsten T. Vala}

\section{OpenEdition}

\section{Journals}

Electronic version

URL: http://journals.openedition.org/chinaperspectives/5949

DOI: 10.4000/chinaperspectives.5949

ISSN: 1996-4617

\section{Publisher}

Centre d'étude français sur la Chine contemporaine

\section{Printed version}

Date of publication: 1 October 2012

Number of pages: $43-52$

ISSN: 2070-3449

\section{Electronic reference}

Carsten T. Vala, "Protestant Christianity and Civil Society in Authoritarian China », China Perspectives [Online], 2012/3 | 2012, Online since 01 October 2015, connection on 28 October 2019. URL : http:// journals.openedition.org/chinaperspectives/5949; DOI : 10.4000/chinaperspectives.5949 


\title{
Protestant Christianity and Civil
}

\section{Society in Authoritarian China}

\author{
The Impact of Official Churches and Unregistered "Urban Churches" on Civil Society \\ Development in the 2000s
}

CARSTEN T. VALA

\begin{abstract}
Religious groups can reinforce, complement, or undermine authoritarian domination. This article investigates whether high-status Protestant churches act as democratising civil society organisations by gathering hundreds of Protestants openly outside state structures to change church registration policies. In so doing, they also seek to curtail state domination over religion and, by extension, over all groups in society.
\end{abstract}

KEYWORDS: civil society, Protestant Christianity, house churches, authoritarianism.

$\mathrm{R}$ eligious groups can play different roles in an authoritarian context.(1) They can strengthen a regime's political power by actively supporting its legitimacy, promoting its values, and reinforcing the domination of ruling institutions; ${ }^{(2)}$ they may complement authoritarian rule by fulfilling needs and providing services not offered by the state; or they may offer a counterweight to a regime by promoting alternative values and by seeking to restrict state authority over society. ${ }^{(3)}$ The complex roles that religious groups play depend partly on the regime and its capacity to persuade, monitor, and coerce them to follow its lead. It also depends on whether religious groups see the regime's priorities as beneficial, accommodating, or, if they reject the authorities' agenda, whether they have the capacity to resist domination and propagate their own values.

One way to investigate the political impact of religious groups is by using the concept of civil society, which has many competing formulations. ${ }^{(4)}$ One of the most popular conceptualisations draws on Tocqueville's thinking and links civil society to democratisation, as citizens participate voluntarily in autonomous associations that counterbalance state power. ${ }^{(5)}$ This version of civil society combines an institutional dimension, in the independence of organisations that enjoy legal protection from state intervention, with specific cultural content such that citizen participation cultivates social capital, the norms and values characteristic of "civil" behaviour. ${ }^{(6)}$ Such a democratising form of civil society pluralises political power because organisations in society represent interests to the state, set limits to state power, and produce behaviour to improve the functioning of state and society.

\section{The question of civil society in the religious context of China}

Authoritarian regimes such as the Chinese Communist Party-state do not recognise any legal framework protecting social organisations. ${ }^{(7)}$ Further, because many organisations in China mix party-state guidance with societal initiative, lack full autonomy, and draw near to the state to gain resources, civil society is often conceptualised as an intermediary sphere of voluntary associations between state and family with some degree of autonomy from

1. This article is made possible by the willingness of Protestants in China to discuss their work. I gratefully acknowledge their cooperation; the generous financial support of several institutions (Chiang-Ching Kuo Foundation, Harvard Yenching Institute, University of California, Berkeley, and Loyola University Maryland); and helpful comments on earlier drafts by Erik Baekkeskov, two anonymous reviewers, and the journal editors.

2. Hank Johnston and Józef Figa, "The Church and Political Opposition: Comparative Perspectives on Mobilization Against Authoritarian Regimes," Journal for the Scientific Study of Religion, 1988, p. 33.

3. A useful introduction to the enormous literature on the "disruptive" role of religion is Christian Smith, Disruptive Religion: The Force of Faith in Social-Movement Activism, Psychology Press, 1996. Much work has been done by social scientists on Christianity's impact on authoritarian regimes, such as Samuel P. Huntington, "Religion and the Third Wave," National Interest vol. 24, no. 3, 1991, pp. 29-42; Maryjane Osa, Solidarity and Contention: Networks of Polish Opposition, Minneapolis, University of Minnesota Press, 2003; Anthony Gill, Rendering Unto Caesar: The Catholic Church and the State in Latin America, University of Chicago Press, 1998; Karl-Dieter Opp et al., Origins of a Spontaneous Revolution: East Germany, 1989, University of Michigan Press, 1996; Hyug Baeg Im, "Christian Churches and Democratization in South Korea," in Tun-Jen Cheng and Deborah A. Brown (eds.), Religious Organizations and Democratization, Case Studies From Contemporary Asia, Armonk (NY), M.E. Sharpe, 2006, pp. 136-156; Murray A. Rubinstein, "The Presbyterian Church in the Formation of Taiwan's Democratic Society, 1945-2004," in Tun-Jen Cheng and Deborah A. Brown (eds.), Religious Organizations and Democratization, op. cit., pp. 109135; on Latin America, see William H. Swatos, Religion \& Democracy in Latin America, New Brunswick (NJ), Transaction Publishers, 1995.

4. The civil society literature is also extensive. See, e.g., Jean L. Cohen and Andrew Arato, Civil Society and Political Theory, Cambridge (MA), The MIT Press, 1994; John R. Ehrenberg, Civil Society: The Critical History of an Idea, New York, NYU Press, 1999; Ernest Gellner, Conditions of Liberty: Civil Society and Its Rivals, London, Hamish Hamilton, 1994; John Keane, Civil Society: Old Visions, New Images, Stanford (CA), Stanford University Press, 1998; Adam Seligman, The Idea of Civil Society, New York, Free Press, 1992

5. Michael Walzer, "The Idea of Civil Society," Dissent, Spring 1991, pp. 293-304. I draw from Muthiah Alagappa's excellent synthesis in his chapter, "Civil Society and Political Change, an Analytical Framework," in Muthiah Alagappa (ed.), Civil Society and Political Change in Asia, Expanding and Contracting Democratic Space, Stanford University Press, 2004, pp. 27, 31.

6. Putnam's 1993 book is the classic argument for social capital production as explaining the functioning of liberal democracies. Robert D. Putnam, Robert Leonardi, and Raffaella Y. Nanetti, Making Democracy Work, Civic Traditions in Modern Italy, Princeton, 1994.

7. Marcia A. Weigle and Jim Butterfield, "Civil Society in Reforming Communist Regimes: The Logic of Emergence," Comparative Politics, vol. 25, no. 1, October 1992, pp. 1-23. 
the state. ${ }^{\left({ }^{8}\right)}$ Policies require registration for groups to operate openly while intrusive regime structures may stunt their ability to identify and defend their interests. ${ }^{\left({ }^{9}\right)}$ First, whether groups defend their interests needs to be investigated, and organisational autonomy, international media attention, and the possibility of playing complex institutions against each other ${ }^{(10)}$ can all help. Second, religious groups may promote alternative values that spur behaviour for the common good by providing for weaker or poorer citizens, or groups may echo political support for the regime agenda. Third, religious organisations as democratising civil society must have a transformative impact on wider politics. In this article, I view civil society as simply the intermediate associational realm between state and family with some autonomy, which means most religious groups qualify as civil society. But to act as a democratising civil society group that undermines authoritarian rule, a religious group must offer alternative values to the regime's agenda, protect the interests of religious institutions against state encroachment, and limit state authority and power (but not only for its own interests). ${ }^{(11)}$

The regime's values centre on its legitimation agenda by which the Chinese Communist Party-state promotes state-led nationalism, economic development, and social stability in a quest to build a prosperous country. ${ }^{(12)}$ The regime justifies its rule by rallying citizens around a cultural identity as citizens of a Chinese state, boasting of increases in GDP, and asserting power to maintain domestic peace as China's national profile rises in the world, leading to values of wealth and economic development, state-led nationalism, and party-state power. ${ }^{(13)}$ Officials encourage (or shift) values promoted by religious and social organisations such that they fall in line with its agenda. ${ }^{144}$

Before delving into the contribution of Protestants to civil society, we gain a brief lay of the land with an abbreviated sketch of other religious groups, choosing Buddhism and Daoism/popular religions for two reasons. First, as the two largest religious populations in the country, they are important for demographic reasons. Second, unlike Protestants (and Catholics, Muslims, and Tibetan Buddhists), they do not worship a "world-transcending" deity or cherish universal principles that would hold secular rulers to account, as Richard Madsen points out, so they provide a good starting contrast for our later investigation of Protestant civil society. ${ }^{(15)}$

Among the official religions, Buddhism counts the largest population of worshipers in China, with perhaps a hundred million or more participants and more than 20,000 state-sanctioned Buddhist temples and monasteries. ${ }^{16)}$ Scholars studying Chinese Buddhist groups find values that appear to counter the materialistic agenda of the CCP. ${ }^{(17)}$ Older and unemployed lay Buddhists outside temples in Beijing and elsewhere, for example, circulate free Buddhist materials as they make sense of their marginalisation and reform themselves and the morality of wider Chinese society, which they see as corrupted by greed. ${ }^{18)}$ Buddhist sites thus provide alternatives to the CCP's economic success and material wealth narrative.

Buddhist temple leaders also demonstrate the capacity to subvert domination by the party-state. As Yoshiko Ashiwa and David L. Wank have shown, Buddhists in Xiamen have organised in shifting alliances with national and local party-state cadres and with Buddhist association leaders at different levels to play one against the other to defend temple interests and ward off revenue-hungry local state officials seeking to control temple income. ${ }^{(19)}$ At the same time, Buddhist leaders act in ways to complement and even strengthen local authorities' rule. They have become willing partners in economic development by generating local state revenue through temple construction projects, by hosting celebrations, and by setting up tourist attractions for Buddhist adherents, with the most visible example being the Shaolin Buddhist Temple and its reality television shows. ${ }^{(20)}$ Buddhist institutions have also begun to complement the regime by fulfilling social welfare needs by offering healthcare, educational funding, and homes for the elderly. (21) Ideologically, Buddhist leaders have declared that "Communism is in accordance with the fundamental spirit of Buddhism," giving such wholehearted support for the regime and its state-led nationalism that authorities have held them up as models for all leaders of official religions. ${ }^{(22)}$ As lay adherents left behind by rapid modernisation find spiritual succour and activist temple leaders demonstrate the ability to defend Buddhist interests, many other Buddhist leaders show that Buddhist institutions can accommodate,

8. Gordon White, et al., In Search of Civil Society: Market Reform and Social Change in Contemporary China, New York, Oxford University Press, 1996, p. 3; Jude Howell, "New Directions in Civil Society: Organizing Around Marginalized Interests," in Jude Howell (ed.), Governance in China, Lanham (MD), Rowman and Littlefield, 2004, pp. 143-171.

9. I recognise that implementation and policy are two separate phenomena in China, and that organisations vary greatly in their registration status, but I refer here to policies for social organisations and religious organisations. Tony Saich, "Negotiating the State: The Development of Social Organizations in China," The China Quarterly, vol. 161, no. 1, 2000, pp. 124-141. Kim-Kwong Chan and Eric Carlson, Religious Freedom in China: Policy, Administration, and Regulation, Santa Barbara (CA), Institute for the Study of American Religion, 2005. On variation in registration, see Timothy Hildebrandt, "The Political Economy of Social Organization Registration in China," The China Quarterly, vol. 208, no. 4, 2011, pp. 970-989.

10. Xiamen Buddhist monks are adept at utilising complex institutions to defend temple goals. Yoshiko Ashiwa and David L. Wank, "The Politics of a Reviving Buddhist Temple: State, Association, and Religion in Southeast China," Journal of Asian Studies, 2006, vol. 65, no. 2, pp. 337-359.

11. Certainly, if a religious group confronts state authority and seeks to limit its power without trying to dominate the state (or by acting in "uncivil" ways, by exercising violence), it also constitutes a civil society group. But this is a very high bar, which few groups would meet.

12. Regime legitimacy rests on the CCP's maintenance of economic growth, nationalism, and ideological continuity, according to Bruce Gilley and Heike Holbig, "The Debate on Party Legitimacy in China: A Mixed Quantitative/Qualitative Analysis," Journal of Contemporary China, vol. 18, no. 59, 2009, pp. 339-358.

13. Official or state-led nationalism is not synonymous with cultural nationalism, but for state nationalists, culture is a tool. See Guo Yingjie, Cultural Nationalism in Contemporary China: The Search for National Identity Under Reform, London/New York, RoutledgeCurzon, 2004, p. 17.

14. Ryan Dunch, "Christianity and 'Adaptation to Socialism,," In Mayfair Mei-hui Yang (ed.), Chinese Religiosities: Afflictions of Modernity and State Formation, Berkeley, University of California Press, 2008, pp. 155-78.

15. Richard Madsen, "Back to the Future: Pre-modern Religious Policy in Post-Secular China," Templeton Lecture on Religion and World Affairs, Foreign Policy Research Institute, Philadelphia (PA), delivered March 2010, http://www.fpri.org/enotes/201003.madsen.postsecularchina.html (consulted on 15 August 2012)

16. Xinhua News Agency, "The Great Practice of the Freedom of Religious Belief, A Summary of the 60 Years of Religious Affairs since the Establishment of New China," 4 September 2009, as reported in Fenggang Yang, Religion in China, Survival and Revival under Communist Rule, op. cit., p. 94.

17. This paragraph from Gareth Fisher, "Universal Rescue: Re-making Post-Mao China in a Beijing Temple," Ph.D. dissertation, University of Virginia, 2006.

18. Ibid.

19. Yoshiko Ashiwa and David L. Wank, "The Politics of a Reviving Buddhist Temple," art. cit.

20. Sun Yanfei, "The Chinese Buddhist Ecology in Post-Mao China: Contours, Types and Dynamics," Social Compass, vol. 58, no. 4, 2011, pp. 498-510; Tim Oakes and Donald S. Sutton, "Introduction," In Tim Oakes and Donald S. Sutton (eds.), Faiths on Display: Religion, Tourism, and the Chinese State, Lanham (MD), Rowman and Littlefield, 2010, p. 18; Robert P. Weller and Sun Yanfei, "The Dynamics of Religious Growth and Change in Contemporary China," in Joseph Fewsmith (ed.), China Today, China Tomorrow: Domestic Politics, Economy, and Society, New York, Rowman and Littlefield, 2010, pp. 29-50. The same phenomenon is as true in the southwest as in inland regions, as local officials cooperate with ethnic minority Buddhists in Yunnan Province to build temples that bring in revenue for the state. Thomas Borchert, "The Abbot's New House: Thinking about How Religion Works among Buddhists and Ethnic Minorities in Southwest China," Journal of Church and State, vol. 52, no. 1, 2010, pp. 1-26.

21. André Laliberté, "Buddhist Charities and China's Social Policy, an Opportunity for Alternate Civility?", Archives des Sciences Sociales des Religions, vol. 158, 2012, pp. 95-117. Zhang Chunjiang, "Zhongguo dangdai fojiao de gongyi shiye" (Buddhist charity in contemporary China), in Zhang Shijiang et al., Zhongguo zongjiao gongyi shiye de huigu yu zhanwang (A retrospection and expectation of the faith-based social services in China), Beijing, Zongjiao wenhua chubanshe, 2008, pp. 188-199.

22. Fenggang Yang and Wei Dedong, "The Bailin Buddhist Temple: Thriving under Communism," in Fenggang Yang et al. (eds.), State, Market, and Religions in Chinese Societies, Leiden (Netherlands), Brill, 2005, pp. 81-82, citing the Chan magazine vol. 2002, no. 1. 
complement, and even "strengthen the resilience of [the] current regime." (23)

It is difficult to ascertain the number of Daoist and popular religion practitioners, but the number of official Daoist temples doubled to 3,000 in the 14 years from 1995 to 2009. (24) On the one hand, Daoist temples have benefited from the increasing levels of economic development, as tourists have patronised Daoist sites, and local cadres have realised that Daoist temples can even draw foreign investment into local public works. ${ }^{(25)}$ On the other hand, local temple networks and lineage halls have functioned like "China's second government" because they offer social and cultural services, build infrastructure, and enjoy high prestige in areas where local cadres lack resources and have exceeded budgets. (26) This complementary and substitutionary role of Daoism and popular religion for the party-state is evident in rural areas, but in cities such as Shanghai where the party-state's institutions are strong enough to enforce its values on Daoist institutions, the transformation in religious practices and values is dramatic. (27) There, Shanghai Daoist Association leaders altered traditional Daoist values from "equality, moderation, and benevolence" to priestly competition, increased efficiency, and material wealth. ${ }^{(28)}$ Priests attended classes to gain an "entrepreneur[ial] spirit," and their wages were tied to ritual performances, as customary values such as "staying with poverty and enjoying the Way" were replaced with new commercial tenets, such that young priests began to call one another "boss (laoban)" rather than "senior fellow Daoist (daozhang)." (29) Overall, like Buddhism, Daoism's relationship with the state exhibits a complementary as well as a predatory dimension. ${ }^{(30)}$

This brief glance across Buddhist and Daoist religious groups, though in no way meant to capture the full diversity of religious expression or interaction, shows remarkable variety in the types of relationships that exist between these groups and state authorities. Even so, it is clear that they operate far more often in ways that are complementary to, or even substitute for, the regime than they do in ways that are conflictual (or that restrict the party-state).

Protestant groups, by contrast, are an important case study for civil society's development in China's religious realm for three reasons. First, Protestant churches in China early on claimed independence from the state and provided the model for the state's institutionalisation of religion in twentieth-century China. ${ }^{(31)}$ To the extent that other religions evolve along the lines of Protestantism, study of its development may hold lessons for their future changes. Second, the separation of religion, specifically of Protestant churches, from political power in feudal Europe was instrumental in the historical development of civil society in Western European countries. ${ }^{(32)}$ Third, in the twentieth century in Europe, Protestant (and Catholic) churches played key roles in mobilising groups in civil society that triggered the downfall of Eastern European Leninist regimes. ${ }^{(33)}$ If Christian churches elsewhere helped promote autonomous, critical forms of civil society and hastened the demise of Communist regimes, they should be studied in China. Yet in order to grasp how Protestant Christian groups might challenge (or complement) regime power in particular, we will need to take a closer look at the overall regime ideology, structures, and policies on religion.

This essay draws primarily on nearly 40 interviews I conducted between 2009 and 2010 during five months of fieldwork among Protestant leaders and members of the Three Self Patriotic Movement and Christian Council associations (or TSPM/CC), provincial and regional seminaries, and official churches as well as in unregistered churches. Because interviewees were developed through snowball sampling, the data are not meant to be statistically representative of the Chinese Protestant churches although they do come from a range of urban areas (cities, provincial capitals, and Beijing) and provinces (south-eastern coastal areas, the central region, and the Northeast). I also draw upon guides to religious affairs issues, cadre training handbooks, and research conducted by Chinese scholars. I refer to "official churches" that are registered with the state and affiliated with the TSPM association because they have official authorisation and are staffed by leaders trained (or at least approved) by the TSPM, whereas because not all Protestant "house" churches meet in private homes, I use the broader term "unregistered churches" to encompass congregations that meet in rented office space and to emphasise that these churches lack formal state approval.

\section{The Chinese Communist Party-state and Protestant Christianity}

I have suggested that democratising forms of civil society that undermine regime power should offer alternative values, defend institutional interests, and limit state authority. Hence we must begin by asking how the Chinese Communist Party-state seeks to impose its own values, override particular interests, and pursue and maintain unrestricted authority.

Richard Madsen offers a helpful starting point in his concept of "neo-imperial sacral hegemony," which links the Chinese state's historical claim to sacred status and unbounded authority over religion to its contemporary self-understanding as a ruling party that guides and authorises society's de-

23. André Laliberté, "Buddhist Charities and China's Social Policy, art. cit., p. 114. See also André Laliberté, "Religion and the State in China: The Limits of Institutionalization," Journal of Current Chinese Affairs, vol. 40, no. 2, 2011, p. 9.

24. Xinhua News Agency, "The Great Practice of the Freedom of Religious Belief, A Summary of the 60 Years of Religious Affairs since the Establishment of New China," art. cit.

25. Chi-Tim Lai, "Daoism in China Today, 1980-2002," The China Quarterly, vol. 174, 2003, p. 418. For another example of temple revival and local income generation, see Fan Guangchun, "Urban Daoism, Commodity Markets, and Tourism," In David A. Palmer and Xun Liu (eds.), Daoism in the Twentieth Century: Between Eternity and Modernity, Berkeley, California University Press, 2012, p. 112.

26. Kenneth Dean, "Further Partings of the Way," art. cit., p. 184. Kenneth Dean has also explained popular religious practices such as the Three in One in Fujian Province as local cultural formations that act as "disruptive communities" alongside state forces, rather than as a potentially oppositional civil society. See Kenneth Dean, "Ritual and Space, Civil Society or Popular Religion?", in Timothy Brook et al. (eds.), Civil Society in China, Armonk (NY), M.E. Sharpe, 1997, pp. 172-192.

27. Others argue that popular religion reflects the values of rural society. Graeme Lang, et al., "Temples and the Religious Economy," op. cit., pp. 156-159, 175; Adam Y.Chau, Miraculous Response: Doing Popular Religion in Contemporary China, Stanford University Press, 2006.

28. This section drawn from Yang Der-Ruey, "The Changing Economy of Temple Daoism in Shanghai," In Fenggang Yang et al. (eds.), State, Market, and Religions in Chinese Societies, Leiden (Netherlands), Brill, 2005, pp. 115, 117, 119-125.

29. Ibid.

30. Its ritual practices are also so closely tied to those of popular religion that they are difficult to separate. Kenneth Dean, "Further Partings of the Way: The Chinese State and Daoist Ritual Traditions in Contemporary China," In Yoshiko Ashiwa and David L. Wank (eds.), Making Religion, Making the State, the Politics of Religion in Modern China, Stanford University Press, 2009, p. 180.

31. David A. Palmer, "China's Religious Danwei, Institutionalising Religion in the People's Republic," China Perspectives, 2009/4, p. 18; Mayfair Mei-hui Yang, "Introduction," in Mayfair Mei-hui Yang (ed.), Chinese Religiosities: Afflictions of Modernity and State Formation, Berkeley, University of California Press, 2008, p. 12.

32. B. Michael Frolic makes this point in B. Michael Frolic, "State-Led Civil Society," in Timothy Brook et al. (eds.), Civil Society in China, Armonk (NY), M.E. Sharpe, 1997, pp. 46-67. This took shape as the formation of national churches separate from the Catholic Church in the Reformation. At the broadest, comparative historical level, new findings argue that the presence of Protestant missionaries explains better the subsequent development of democracy worldwide than other traditional theories do. See Robert D. Woodberry, "The Missionary Roots of Liberal Democracy," American Political Science Review, vol. 106, no. 2, 2012, pp. 244-274.

33. Maryjane Osa, Solidarity and Contention, op. cit:; Karl-Dieter Opp et al., Origins of a Spontaneous Revolution, op. cit. The CCP is well aware of churches' role in hosting opposition forces against the Communist regimes in the 1980s, as they sent scholars to study the phenomenon. Gong Xuezeng, Shehuizhuyi yu zongjiao (Socialism and religion), Beijing, Zongjiao wenhua chubanshe, 2003, chapter 5. 
velopment. (34) Historically, the Chinese state, whether in its imperial, Republican, or Communist periods, has held itself as the supreme authority above all religious actors. ${ }^{(35)}$ Drawing on Xi Jinping's 2008 declaration that the Party was now a "ruling party," Madsen argues that the CCP sees itself as carrying out a sacred national mission, part of which is to promote particular values to develop the economy, defend the motherland, and promote its "cultural heritage." (36) In these values, the party-state therefore continues to claim the imperial dynastic state's sacred aura and dominant authority over society.

Setting off from Madsen's idea of "neo-imperial sacral hegemony," we'll analyse the values that have particular impact in the religious realm, as they take shape through the party-state's corporatist structures, its ideology of state-led nationalism above religious faith, and evolving policies toward religion's engagement in societal issues.

First, shortly after taking power in 1949, the CCP supported collaborationist religious leaders to set up national associations for Protestant Christianity and the other four official religions (Buddhism, Catholicism, Daoism, and Islam), under which all religious sites had to affiliate or be shuttered. (37) Because CCP historiography links closely the Christian churches and foreign imperialism, the Protestant and Catholic associations were also required to include "patriotic" in their names, signifying their questionable loyalty to the CCP. (38) Today, the same corporatist structures persist, with this hierarchy of religious associations and two major organs of the party and state all overseeing the official religions. The party bureaucracy comprises the United Front Work Department (UFWD), which wields the greatest influence in religious affairs and deals with religious leaders individually, while the state organs are the national-level State Administration of Religious Affairs (SARA) and local offices of the Religious Affairs Bureaus (RAB), which take charge of day-to-day monitoring of religious affairs. ${ }^{(39)}$ All religious sites and personnel must register with the state and affiliate with their respective associations, so that official Protestant churches fall under the authority of the Three Self Patriotic Movement (TSPM) association and its sister organisation, the Christian Council (CC). ${ }^{(40)}$ The associations in turn are integrated into the party-state structure, because the regime sanctions and legitimises the associations, appoints their leaders, and claims to protect "normal" religious expression by eradicating groups that lack state-granted legitimacy. ${ }^{(41)}$ Although the CCP no longer regularly exercises the same coercive power to impose control through its various institutions as in the Mao era, the structures nonetheless ensure that Protestants in official churches worship within the public framework of regime authority over society.

Second, in addition to the organisational structures of domination over religion, the CCP has also endeavoured to shape the values and beliefs of religious leaders and adherents within those structures in line with its ideological agenda. According to the Constitution, the CCP views religious believers as outside of its (secular) definition of the nation, but allows them an avenue to join the nation by supporting the leadership of the CCP as part of their "love of country" or patriotism. ${ }^{(42)}$ To inculcate this patriotism centred on the CCP among rising Protestant leaders, official Protestant seminaries promote the slogan and coursework for the "mutual adaptation of religion to socialist society" in patriotic education classes, for which national government offices have developed standard textbooks. ${ }^{(43)}$ The goal is to minimise differences between non-believers and religious believers such that all Chinese unify politically under the leadership of the CCP.

Some scholars view the CCP's structuring of religion through organisation and ideology as largely "creating the discursive framework" (44) for interac- tions by cadres and religious leaders and others, although I suggest that this underplays the power differential between state actors and religious leaders and the party-state's power to determine which actors legitimately belong in the public realm of society. Certainly, the reform-era party-state does not forcefully impose its religion policies as the Mao-era regime did. ${ }^{(45)}$ And, in the reform era, the party-state does rely more on persuasion than coercion to manage religious affairs. ${ }^{(46)}$ Yet, as Madsen's neo-hegemony suggests, the party-state still asserts supreme authority and reserves the exercise of coercive power when necessary to supplement its powers of persuasion, so that even if the power imbalance has lessened between cadres and religious leaders, it is certainly still present.

As a result, Protestant associations and their leaders play a more central role than before, because cadres from the regime's institutions for monitoring and containing Protestants' activities hold little religious legitimacy or persuasive power for Protestants. According to the director of the national State Administration of Religious Affairs, association leaders have such influence and status that they can "play a role that the party-state cannot" among believers. ${ }^{(47)}$ Of course, the dominant party-state is not monolithic; rather it is highly fragmented and varies in efficacy from area to area. The TSPM/CC associations therefore exhibit considerable variation in their capacity or desire to monitor and restrain grassroots official church activities. On one end, powerful, activist TSPM/CC associations, as in Harbin, weaken pastor-believer ties by restricting grassroots pastors' time with congregations by controlling church committees, reassign popular pastors from key churches to outlying churches (to avoid challenges to associational leaders'

34. Richard Madsen, "Back to the Future: Pre-modern Religious Policy in Post-Secular China," art. cit.

35. Anthony C. Yu, State and Religion in China, Chicago, Open Court, 2005; Goossaert and Palmer also note that the state-sponsored push to shape popular morality has not ended in the postMao era, but has only taken different shape. Vincent Goossaert and David A. Palmer, The Religious Question in Modern China, University of Chicago, 2011, p. 194.

36. Richard Madsen, "Back to the Future: Pre-modern Religious Policy in Post-Secular China," art. cit.

37. Richard C. Bush, Religion in Communist China, New York, Abingdon Press, 1970.

38. And only in the mass campaigns that accompanied the lead-up to China's entry into the Korean War did increasing numbers of Protestants sign on to support the new associational structures under CCP authority.

39. Alan Hunter and Kim-Kwong Chan, Protestantism in Contemporary China, New York, Cambridge University Press, 1993.

40. Kenneth G. Lieberthal et al. (eds.), Bureaucracy, Politics, and Decision Making in Post-Mao China, Berkeley, University of California Press, 1992. As Kindopp notes, the Christian Council was originally intended to replace the TSPM because the TSPM's reputation was so tarnished in the eyes of many Protestants by its harassment of Protestants in the Mao era. Jason Kindopp, "The Politics of Protestantism in Contemporary China: State Control, Civil Society, and Social Movement in a Single Party-State," Ph.D. Dissertation, George Washington University, 2004

41. On co-optation of religious and social organisations through state corporatism, see Mary E. Gallagher, "The Limits of Civil Society in a Late Leninist State," in Muthiah Alagappa (ed.), Civil Society and Political Change in Asia, op. cit., pp. 419-452. On state control of Protestants, see Carsten T. Vala, "Pathways to the Pulpit: Leadership Training in 'Patriotic' and Unregistered Chinese Protestant Churches Leaders," in Yoshiko Ashiwa and David Wank (eds.), Making Religion, Making the State, op. cit., pp. 126-150. Thanks to Roskilde University professor Lisbet Christoffersen for pointing out that state churches also can be sources of civil society.

42. Ryan Dunch, "Christianity and 'Adaptation to Socialism'," op. cit., p. 163; Yingjie Guo, Cultural Nationalism in Contemporary China, op. cit., p. 42; Carsten T.Vala, "Protestant Reactions to the Nationalism Agenda in Contemporary China," in Francis K.G. Lim, Christianity in Contemporary China, Socio-cultural Perspectives, New York, Routledge, 2012.

43. Ibid. For the patriotic education textbooks, see Cheng-tian Kuo, "Chinese Religious Reform," Asian Survey, vol. 51, no. 6, 2011, pp. 1042-64.

44. David A. Palmer, "China's Religious Danwei," art. cit., p. 21;Vincent Goossaert and David A. Palmer, The Religious Question in Modern China, op. cit., p. 321.

45. Tibetan Buddhists and Uyghur Muslims have a different perspective on the reform-era regime's actions.

46. Nanlai Cao, Constructing China's Jerusalem: Christians, Power, and Place in Contemporary Wenzhou, Stanford University Press, 2010, p. 7.

47. Wang Zuo'an, Zhongguo de zongjiao wenti he zongjiao zhengce (The religious issues and religious policies of China), Beijing, Zongjiao wenhua chubanshe, p. 314. 
authority), and refuse to ordain aspiring pastors they deem to be "untrustworthy." ${ }^{(48)}$ At the other end, grassroots official church leaders have reported remarkable autonomy under weak TSPM/CC associations in places such as Changchun, where they spend much time with congregants modelling humble leadership, launch illegal domestic missionary teams to remote provinces, and preach and teach exactly as they see fit. ${ }^{(49)}$ (Outside of important political centres such as these provincial capitals, Protestants report some associations to be ineffectual or even non-existent in the daily life of grassroots official churches. $\left.{ }^{(50)}\right)$

Similarly, although the party-state's call for the "mutual adaptation of religion and socialist society" signals the regime's power to direct in broad strokes Protestant teachings, the actual details are worked out in uneven fashion in various official Protestant seminaries. TSPM pastors have reported fuller implementation of its Protestant expression as "Theological Reconstruction" in seminaries under top TSPM/CC leaders' control, while it has been undermined or resisted in much of the rest of the country. ${ }^{(51)}$ Ryan Dunch characterises the "Theological Reconstruction" push as part of a "long conversation" with Protestant leaders. ${ }^{(52)}$ Yet whether the party-state sets the framework or is in some form of dialogue with Protestant leaders over its religious management, it is still, to carry the metaphor to its breaking point, the CCP that decides when to start, stop, and interrupt the dialogue. An unequal (and at least potentially coercive) relationship exists between party-state cadres and Protestant association leaders on one side and grassroots official church leaders and adherents on the other. ${ }^{(53)}$

This more moderate but still lopsided power relationship takes yet another form in the religion policies of the last several decades. After the Cultural Revolution ended, the CCP issued Document 19 in 1982 to reverse its policy of religion suppression while reaffirming that religions would disappear once material conditions improved. ${ }^{(54)}$ Local and provincial levels of government then promulgated increasingly more (and longer) religion regulations in the aftermath of the 1989 Tiananmen Square crackdown, partly as an attempt to bring religious affairs under regulatory control and partly to grant its control a degree of legal legitimacy. ${ }^{(55)}$ This regulatory push culminated in the 2004 Regulation on Religious Affairs, called a "paradigm shift" by officials for its (largely unrealised) promises to limit bureaucratic abuse of power and ease direct registration of churches with the state. ${ }^{(56)}$ These regulations utilise language so imprecise and definitions so vague that local cadres continue to enjoy great leeway and few constraints in dealing with religious affairs. ${ }^{(57)}$ However, one area in which religious affairs cadres enthusiastically embraced religious initiatives was in tourism and the provision of charitable services, such as funding indigent student scholarships, providing elder care, and setting up medical clinics. Religious groups launched into these activities after President $\mathrm{Hu}$ Jintao announced during the $17^{\text {th }}$ Chinese Communist Party Congress in 2007 that religious believers could play a "positive role... in promoting economic and social development." (58) Religions were free to play a helping role for the party-state.

\section{Protestants and democratising civil society}

Regardless of the extent to which the party-state since the early 1980s has modified its structures over Chinese Protestant churches (very little), lessened its ambition to alter Protestant doctrines and practices (some), and improved its regulations towards churches (more, even if actual results vary), the question remains whether Protestant churches act as sites of democratic civil society. According to our working definition, Protestant churches must offer alternative values, defend institutional interests, and limit state power. The question is important not only because of the historical and comparative reasons given earlier. Protestants also constitute a rapidly growing portion of the population, and thus are a source of worry for CCP cadres who fear their disloyalty. By official count, which tallies only those aged 18 or older and who worship in officially registered sites, Protestant numbers exploded from three million in 1982 to 15 million in 1999. ${ }^{(59)}$ Contemporary estimates of the number of all Protestants in official and unregistered venues range widely, with overseas journalists' estimates running as high as 100 million, ${ }^{(60)}$ while more conservative estimates suggest 40 million to 60 million Chinese Protestants. (61) Whatever the precise numbers, the warning of top CCP officials echoes those in Protestant seminary textbooks about the "foreign enemy forces" that seek to "destroy the socialist motherland," while scholars at the Central Party School in Beijing blamed Eastern European churches for being instruments of "Western enemy forces" to spur the collapse of Communist regimes. ${ }^{(62)}$

I begin by exploring the question of Protestants and civil society in the setting of the official churches, seminaries, and TSPM/CC associations, and then turn to Protestants worshiping in unregistered churches. ${ }^{(63)}$

48. Interviews with current and former TSPM pastors, November 2002, June 2006.

49. Interviews with several current grassroots official church leaders, Changchun, July 2009, August 2010.

50. Interviews, July 2009. Interview, November 2002

51. Ryan Dunch recognises Theological reconstruction as "out of step" with the majority of Protestant believers in Dunch, "Christianity and 'Adaptation to Socialism'," art. cit., p. 178, while Jason Kindopp describes concerted resistance throughout the TSPM hierarchy. See Jason Kindopp, "The Politics of Protestantism in Contemporary China: State Control, Civil Society, and Social Movement in a Single Party-State," op. cit., pp. 291-362.

52. Dunch, "Christianity and 'Adaptation to Socialism'," art. cit., pp. 172, 156, citing Jean Comaroff et al., Of Revelation and Revolution, Volume 1: Christianity, Colonialism, and Consciousness in South Africa, University of Chicago, 1991.

53. Ibid.; David A. Palmer, "China's Religious Danwei," art. cit.; Vincent Goossaert and David A. Palmer, The Religious Question in Modern China, op. cit., all acknowledge that the Protestant-state relationship is unequal, but my interviews suggest that it plays a greater role in shaping the way critical Protestants in the official associations and grassroots churches view the regime. The legacy of Protestant Christianity's ties to foreign imperialism also exacerbates the sense among these Protestants that the regime opposes Christianity's development.

54. Donald E. Maclnnis, Religion and Policy in China Today, Maryknoll (NY), Orbis Books, 1989.

55. Carsten T. Vala, "Failing to Contain Religion: The Emergence of a Protestant Movement in Contemporary China," Ph.D. dissertation, Berkeley, University of California, 2008.

56. Eric R. Carlson, "China's New Regulations on Religion: A Small Step, Not a Great Leap, Forward," BYU Law Review, no. 3, 2005, pp. 747-797. Kim-Kwong Chan and Eric Carlson, Religious Freedom in China, op. cit.

57. Eric R. Carlson, "China's New Regulations on Religion," art. cit.

58. Hu Jintao, "Hold High the Great Banner of Socialism with Chinese Characteristics and Strive for New Victories in Building a Moderately Prosperous Society in All, Report to the Seventeenth National Congress of the Communist Party of China on Oct. 15, 2007," accessed 22 June 2012, published 25 October 2007, Xinhua News Agency, http://www.china.org.cn/english/congress/ 229611.htm (consulted on 15 August 2012); André Laliberté, et al., "Religious Philanthropy and Chinese Civil Society," in David A. Palmer, et al. (eds.), Chinese Religious Life, New York, Oxford University Press, 2011, pp. 139-151.

59. Fenggang Yang, Religion in China, Survival and Revival under Communist Rule, op. cit., p. 93.

60. David Aikman, Jesus in Beijing: How Christianity is Transforming China and Changing the Global Balance of Power, Washington DC, Regnery, 2006, p. 8.

61. Carsten T.Vala, "Pathways to the Pulpit," art. cit., p. 120, fn. 1. A 2007 nationwide survey put the number of all Protestants at more than 30 million. Horizon Research, Horizon Life Satisfaction Survey, 2007.

62. Zhongguo jidujiao sanzi aiguo yundong (China Protestant Three Self Movement), Jidujiao aiguozhuyi jiaocheng (Shiyongben) (Protestant patriotic curriculum [Trial edition]), Beijing, Zongjiao wenhua chubanshe, 2006, pp. 439-41. Gong Xuezeng, Shehuizhuyi yu zongjiao (Socialism and religion), op cit., p. 148.

63. There is a substantial Protestant population that worships in both registered churches and unregistered settings as well. This constitutes part of what Fenggang Yang calls the "gray market" of ambiguous legality, between the official churches and unregistered churches. See Fenggang Yang, "The Red, Black, and Gray Markets of Religion in China," The Sociological Quarterly, vol. 47, no. 1, 2006, pp. 93-122. 
One way to assess the capacity of official Protestant churches to play the role of democratising civil society organisations is to interview Protestant TSPM/CC association leaders (such as TSPM chairpersons or CC directors), seminary officials (such as principals and vice principals), or grassroots church leaders, because they serve in key roles between adherents and the state and because RAB officials frequently rely on them as the front line in keeping track of Protestant activities. ${ }^{(64)}$

The attitudes of such Protestant leaders toward state power offer insights into whether they have been fully co-opted or whether they retain a critical perspective such that the various state-sanctioned Protestant institutions under their watch might act as spaces of civil society. Asked a broad question about the degree of religious freedom for Protestants, these Protestant leaders tended to highlight the improvement in the regime's treatment of religion.

A provincial CC leader in southern China launched into a historical overview of the CCP's steadily more benign view of religion, starting from its original perspective of religion as the "opium of the masses" (in the 1980s), to discussions of "religious freedom" (1997 15 th Chinese Communist Party Congress), religion "harmonising" with socialism (the $200216^{\text {th }}$ Party Congress), and finally religion as "a reliable force to build Chinese socialism" (the 2007 $17^{\text {th }}$ Party Congress). ${ }^{(65)}$ A north-eastern TSPM/CC city leader proudly noted that the CCP had inserted the phrase "policy of freedom of religious belief" into its 2007 constitution, which led to his sunny view that religious freedom is "continually improving, without a doubt... and becoming complete." (66)

Older Protestant TSPM and CC association officials tepidly contrasted the Mao era and today's circumstances as evidence for optimism, perhaps because their traumatic experiences under Mao made them appreciate the contemporary situation. A TSPM/CC director in a small city pointed out that at least the government now permitted Christians to worship publicly. ${ }^{(67)}$ Further, he viewed the state's promotion of "patriotic" education, which others might see as sacrificing religious faith to party-focused political loyalty, as a positive change because the regime replaced the violence of earlier times with persuasion. ${ }^{(68)}$

As the provincial CC leader in southern China pointed out, "Before, the Party looked at religion as oppositional, [but] now religion is a part of society." (69) As an officially sanctioned part of society, Protestants are called upon by the regime to play important roles in meeting societal needs, as President Hu Jintao's 2007 announcement shows. Protestant leaders are eager to do so, yet they complain that they often lack the resources they need. ${ }^{(70)}$ In this context, some official church pastors and leaders go so far as to see the regime as benefitting churches that "need the government's help" by offering the party-state's resources and recognition in society, help without which churches would have a "hard time participating in society." (71) Such Protestants view the regime not as suppressing Protestant churches, as many overseas observers assume, but rather as empowering them.

So far, leaders in the Protestant TSPM/CC associations, seminaries, and churches express willingness to cooperate with the party-state, suggesting that, at least from a leadership view of these Protestant institutions, they appear to play a complementary role as civil society. Official Protestant institutions do not seem to offer alternative or critical values or seek to set limits to state power.

Yet, just because Protestant leaders express agreeable attitudes does not mean that they do not defend institutional interests when necessary. Of course, Protestant leaders do at times argue that Christians need to accommodate to the existing order and could cite Biblical texts for support. For example, the southern China provincial CC director explained that Protestants were better off adapting "according to local circumstances" than taking oppositional stances, because "Jesus...said, 'Give to Caesar what is Caesar's, to God what is Cod's.' He didn't directly make the government lose face...or develop a conflict with the government." (72) Yet, at the same time, more than one savvy TSPM/CC leader made clear that avoiding open conflict did not translate into abject subordination to the regime either. These TSPM/CC leaders or pastors mentioned Jesus's words in the Bible to be "cunning as serpents, innocent as doves," pointing out that being savvy in dealing with authorities was much better than expressing naïve opposition to disagreeable policies. ${ }^{(73)}$

In fact, rather than articulating conflicting interests in a direct manner, official church leaders have manoeuvred around restrictions put in place by the party-state, but in ways that limited the impact on building up norms of democratising civil society. One small city TSPM/CC director learned that his mayor would soon grant long-term land rights to a work unit that was occupying church real estate. ${ }^{(74)}$ He skilfully instructed church staff to threaten street demonstrations by the whole congregation (while to religious affairs officials, he claimed to be unable to stop them) and eventually managed to pry government support for a new church building to be built elsewhere. All this took place without ordinary congregants being involved. An official provincial seminary staff member explained that her Protestant school was replacing state-required political content in the "Theological Reconstruction" curriculum with Protestant teaching that strengthened students' loyalty to church interests. ${ }^{(75)} \mathrm{A}$ provincial seminary leader in a third location led a group of students to storm a church taken over by another state office, eventually paving the way for the TSPM to regain the real estate. ${ }^{(76)}$ Finally, a TSPM/CC Protestant staff worker in a small city circumvented regulations banning evangelism by ignoring local authorities' warnings and growing illegal meetings to 100 new believers before registering them as new, official church congregations. ${ }^{(77)}$ In this way, he made use of his employment in the official association and expanded the number of official churches despite policies forbidding unregistered meetings. In the face of party-state restrictions, Protestant leaders devise ways to pursue their religious goals without revealing strategies to (or involving) common churchgoers.

64. This is only one way, of course, and would be strengthened by grassroots observations inside the Protestant association organisations and the churches they supervise, which I have only done in Harbin and surrounding area churches. I discuss the central role of pastors in Carsten T.Vala, "Pathways to the Pulpit," art. cit., pp. 101-103. Kindopp also discusses the role of TSPM association leaders in projecting regime power. See Jason Kindopp, "The Politics of Protestantism in Contemporary China," op. cit., pp. 180-199.

65. Interview, July 2009.

66. Interview, July 2010.

67. Interview, July 2009.

68. Indeed, his appreciation for more benign party-state policy does not mean that Protestants in the official churches do not defend their interests (this director has both ignored fresh RAB cadres who sought to impose tighter control and adroitly manoeuvred to expand church real estate). Some official church leaders sought to persuade the state that Protestants constituted no danger and in fact were helpful and should be greater in number. Interview, July 2009.

69. Interview, July 2009

70. Idem.

71. Idem.

72. Idem.

73. Idem.

74. Idem.

75. Idem.

76. Idem.

77. Idem. 
Hence, leaders in the Protestant associations, official seminaries, and registered churches may express cooperative attitudes toward the regime, reflecting their status as state appointees in regime-recognised institutions, but at the same time reserve their capacity to outflank the authorities to defend church interests. Some Protestant association officials openly express satisfaction over the change in the party-state's accommodation of religion over the years, and a few Protestants even see the regime as beneficial to Protestantism because it provides resources or recognition for church work. Still, however much they appreciate the party-state's moderated stance on religion, some of these Protestants also forge savvy strategies to manoeuvre around or battle authorities to expand and protect Protestant interests, much like the Xiamen Buddhists studied by Ashiwa and Wank.

In spite of Protestant leaders playing complementary roles in some aspects of their relationship to the party-state, by deploying "cunning" strategies they effectively defend and even advance religious interests. Yet, because much of this strategising and activism occurs within leadership circles, common believers are left unaware of the church-state tensions and the ways in which religious leaders must manoeuvre to resist party-state pressures. The TSPM/CC staff worker who outwitted authorities to found new congregations concluded that the regime's ambition is to "allow you to exist but [it] doesn't want you to grow." Such attitudes are usually not transmitted to congregations, as a TSPM pastor once explained, because the regime warns religious leaders against divulging what happens within official church circles. ${ }^{(78)}$ TSPM/CC leaders likely have their own strategic justifications for limiting wider knowledge in that it lessens their own risk of punishment and increases chances that regime officials will be willing to negotiate an outcome rather than view activism as instances of social instability that require force to suppress them. Keeping such information private may short-circuit important processes of democratic civil society development whereby common believers learn to openly discuss issues of shared concern with religious leaders, followed by joint debate and discussions, after which participants finally settle on the appropriate norms for limits to party-state power. Without such processes of public discussion, activism by Protestant leaders may be effective and successful, but it fails to generate a wider impact and awareness among common believers that might help reinforce civil society behaviour.

\section{Unregistered Protestant urban churches and civil society}

The tens of millions of Protestants who worship in unregistered churches may also contribute to a civil society that offers alternative values, defends church interests, and seeks to limit state authority. These Protestants reject state registration to form autonomous congregations out of principle or for pragmatic reasons. Some remember the Mao-era persecution of Christians by the regime and at the hands of TSPM leaders and refuse to affiliate on principle. ${ }^{(79)}$ Others are not aware of religion regulations or cannot register because no TSPM association exists in their area.

Whether they recall Mao-era traumas or not, many "house church" leaders today view their autonomy as theologically justified because they criticise the Protestant associations and official churches for collaborating with an atheist state and therefore compromising doctrinal purity. ${ }^{\left({ }^{80}\right)}$ Unregistered leaders attack official churches for a variety of reasons: the empty, ritualistic forms of official church services lack spiritual vitality; ${ }^{(81)}$ preaching on missions work is forbidden; ${ }^{(82)}$ relationships between church members in official congregations are shallow; ${ }^{\left({ }^{83}\right)}$ or the state strives to manage and restrict church activities. ${ }^{\left({ }^{84}\right)}$ As many critics have put it in one way or another, "Their [TSPM] head is the Communist Party; our head is Jesus Christ." (85) Overall, unregistered church leaders have condemned the "false" nature of official churches for obeying the party-state rather than obeying God. ${ }^{(86)}$

Membership growth for unregistered churches was most rapid in the countryside in the early reform period. ${ }^{(87)}$ But as Protestants in urban areas gained greater theological training, both in official and unofficial seminaries in China and also abroad, unregistered churches in the cities became better organised and had access to greater resources than rural congregations did. (88) As China's population has become predominantly urban, so has the Protestant population, and it has become younger, more educated, and better internationally connected than before. ${ }^{\left({ }^{89}\right)}$ Duan Qi and Tang Xiaofeng note that the proportion of university students in Shanghai and Beijing who are Protestant is three times and eight times greater than the respective proportion of city residents who are believers. ${ }^{(90)}$

The unregistered churches in the cities can be divided into several types, with some led by factory bosses who established congregations in their workplaces, others that primarily draw migrant workers, and the ones I'm particularly interested in - those located in major urban centres and whose congregations comprise high-status, well-educated, and often wealthier Chinese compared to average urban residents. ${ }^{(91)}$

Some of these urban Protestant leaders have forged a new approach to establishing unregistered congregations and to regime relations by calling themselves an "urban church" (chengshi jiaohui), a geographical description indicating that they see themselves as neither part of the traditional "house churches" nor as part of the "Three Self" official churches. ${ }^{\left({ }^{2} 2\right)}$ These urban churches are unlike house churches in that they don't meet in small groups or prize secrecy or unobtrusiveness; they are unlike official churches in that they refuse to come under Protestant association (TSPM) authority. Instead, the young Protestant leaders of these urban churches view their congrega-

78. Interview, November 2002.

79. Leung Ka-lun, Gaige kaifang yilai de Zhongguo nongcun jiaohui (The rural churches of mainland China since 1978), Hong Kong, Alliance Bible Seminary, 1999.

80. Lydia Lee, A Living Sacrifice, Tonbridge (UK), Sovereign World, 2001, p. 239.

81. Interview, July 2009.

82. Interview, May 2006

83. Interview, July 2009.

84. Interview, May 2006

85. Interviews, February 2003, August 2010. Also, Lydia Lee, A Living Sacrifice, op. cit., p. 239.

86. Ka-lun Leung, Gaige kaifang yilai de Zhongguo nongcun jiaohui, op. cit., pp. 361-363.

87. Ibid.

88. Protestants who graduated from official seminaries have established or run unregistered churches in Shanghai, Wuhan, and Beijing.

89. See Xie Xiahang, "Religion and Modernity in China:Who is Joining the Three-Self Church and Why," Journal of Church and State, no. 52, vol. 1, 2010, pp. 78-80, for the generational changes among young Protestants.

90. Duan Qi and Tang Xiaofeng, "2008 Nian Zhongguo jidujiao xianzhuang ji yanjiu" (The current situation and study of Chinese Protestantism in the year 2008), Annual Report on China's Religions (2009), Jin Ze and Qiu Yonghui (ed.), Beijing, Shehui kexue wenxian chubanshe, 2010, p. 139.

91. Thanks to an anonymous reviewer for the point that many house churches in the city are populated by lower middle class workers and migrant workers. On "boss Christians" and migrant worker churches in Wenzhou, see Nanlai Cao, Constructing China's Jerusalem, op. cit. On "worker churches" (mingongjuhui) and the urbanisation process, see Huang Jianbo, "Chengshihua jinchengzhong de Zhongguo jidujiao" (Chinese Protestant Christianity in the midst of the urbanization process), in Yu Guoliang (ed.), Chaihuile zhongjian geduan de qiang (The walls of separation have been demolished), Beijing, Zongjiao wenhua chubanshe, 2007.

92. Rob Moll, "Great Leap Forward, China is Changing and So Is Its Church. How New Believers Are Shaping Society in Untold Ways," Christianity Today online, accessed 23 May 2008, www.christianitytoday.com/ct/2008/May/19.22.html (consulted on 15 August 2012). 
tions as the next stage beyond house churches, because they are open churches that usually welcome officials and police to visit their services; they are large churches that come together as a single congregation typically in rented office spaces; and they are unregistered churches. Their openness, size, and lack of registration all increase their capacity to influence society because they can accept anyone, have a large enough congregation to constitute a church community, and are not restricted by onerous religion policies.

Membership in this subset of urban churches is distinct from the urban churches populated by poorer urban residents or migrant workers, because the membership of high-status urban churches tends to be populated by those who have college education (or are university students), high-status jobs, or important positions in society. In these urban churches, one or two hundred young professionals from various fields - law, journalism, healthcare, police, university work - most of whom have been Christians for fewer than five years, congregate in the rented office spaces of these unregistered congregations, most of which were formed only a few years earlier. Although these particular urban churches are not as widespread as other types of urban churches, because there are fewer highly educated Protestants than migrant workers in cities, yet a few dozen of these urban churches with 100 or more members and open meetings likely exist in Beijing and other cities such as Guangzhou, Nanjing, Shanghai, Wuhan, and Xi'an. ${ }^{(93)}$

The most prominent of the high-status urban churches is Beijing's Shouwang Church, whose outdoor worship protests against party-state harassment from 2011 to today have captured the attention of international media, including The New York Times and Radio France Internationale. ${ }^{(94)}$ Shouwang Church stands out as an early mover because it formed in the 1990s, grew to a thousand members at its peak, and has maintained its goal of worship as a single large congregation outside state structures. ${ }^{(95)}$ It also aims to influence the public, evidence of which is found in the church name, which means to "stand watch," and in what leaders explain as its ambition to be a "city on a hill."

After a 2005 warning by authorities that it was meeting illegally, Shouwang Church began to generate sustained party-state scrutiny in 2006. The church tested the much-touted national Regulation on Religious Affairs by applying to register directly with the state, matching every provision without affiliating under the Protestant TSPM/CC associations' authority. ${ }^{\left({ }^{96}\right)}$ Not surprisingly, state authorities rejected the registration application and ratcheted up the pressure on the church in the run-up to the 2008 Olympics.

In May 2008, the Beijing government issued a notice reaffirming a ban on all illegal religious meetings. That same month, 30 RAB officials and police barged into a Shouwang Church worship service. (97) State authorities recorded the names, phone numbers, and ID card information of believers and began making phone calls to pressure them to leave the church until the church organised lawyers to instruct members on how to challenge their callers and stop the harassment. When Shouwang Church members refused to cave to regime demands, the authorities tried to disband the congregation in June 2008 by applying pressure on their landlord to force them out. By October 2009, the mounting pressure on their landlord convinced church leaders that they could no longer meet in the rented office building. The next Sunday they organised an outdoor service that would continue congregational worship and also protest publicly against the pressure. International media attention began to grow. ${ }^{(98)}$ On the third Sunday, the day that US President Barack Obama was due to arrive, tensions reached a peak, and
President $\mathrm{Hu}$ Jintao allegedly intervened to prevent an international incident by guaranteeing an indoor site to which the church could move. ${ }^{(99)}$ Nearly two years later, the church is still engaged in weekly outdoor worship protests because the local party-state refuses to allow any Beijing landlord to rent them space. The church leaders remain under house arrest, and week after week, dozens of church members are detained (and released) by police. ${ }^{(100)}$

Shouwang Church has the highest profile of these high-status urban churches not only due to its ongoing struggle with the regime. The church has also since 2007 published a magazine addressing a range of church management and faith issues, the print edition of which is read by other urban church leaders, ${ }^{(101)}$ and it has maintained a website through which it keeps in touch with members, communicates the numbers of outdoor worship participants detained every Sunday, and at one point even offered its side of the story when the CCP state media outlet Global Times editorialised on the church-state conflict. ${ }^{102)}$

In terms of democratic civil society, the attempt by Shouwang Church and other urban churches to alter the church registration policy would likely spill over to breaking the party-state's control of societal organisations. Shouwang Church has been the most active church in defending their interests by attempting registration and launching a series of outdoor worship service protests, but churches in Guangzhou, Shanghai, and Xi'an have held similar outdoor worship services in reaction to local authorities' shuttering of their meeting sites. Further, Shouwang Church's efforts received public support from more than 40 unregistered churches that signed a prayer letter and nearly 20 pastors who signed a petition asking the National People's Congress to resolve the Shouwang Church conflict. ${ }^{(103)}$ Altogether, many of these urban church leaders seek to replace what one church leader called the "unreasonable" policies of state corporatism that lead to "strict control of popular organisations," with the goal of gaining "greater space for every

93. These estimates are based on fieldwork carried out in July and August 2009 and from July to September 2010.

94. Andrew Jacobs, "Chinese Christians Rally Around Underground Church," The New York Times, 13 May 2011, http://www.nytimes.com/2011/05/13/world/asia/13china.html (consulted on $15 \mathrm{Au}$ gust 2012), and Stéphane Lagarde, "Nouvelles arrestations de chrétiens à Pékin," Radio France Internationale, http://www.rfi.fr/asie-pacifique/20110424-nouvelles-arrestations-chretiens-pekin (consulted on 15 August 2012).

95. This paragraph is drawn from Interviews, July 2009; July and August 2010

96. Idem.

97. Interview, July 2010. Wei Dedong and Li Yi, "Dalu jiatingjiaohui de donglijizhi chutan - Yi Beijing $S$ jiaohui weili" (A preliminary investigation into the power mechanism of mainland house churches - taking $S$ church as an example), paper presented at $7^{\text {th }}$ Symposium on the Social Scientific Study of Religion in China, Beijing, 26-27 July 2010, p. 253.

98. Andrew Jacobs, "Chinese Christians Rally Around Underground Church," art. cit.

99. I interviewed the urban church pastor who acted as the go-between in negotiations between the state and Shouwang Church, drawing on relations he cultivated over ten years as an official church pastor in Beijing. Interview, September 2010.

100. Interviews, July and August 2010. As of 7 August 2012, Shouwang Church reported that at least 26 members had been detained, 15 months after the (second set of) worship protests began in April 2011. "Beijing shouwang jiaohui 8 yue 5 ri huwai jingbai tongbao" (Beijing Shouwang communication for August 5 outdoor worship), 7 August 2012, www.shwchurch.org (consulted on 15 August 2012).

101. It now appears online at https://www2.shwforum.info/blog (consulted on 15 August 2012).

102. "Gebie jiaohui yao bimian rang ziji zhengzhihua" (Some churches should not allow themselves to be politicized), Huanqiu (Global Times) website, 26 April 2011, http://opinion.huanqiu.com/roll/ 2011-04/1652371.html (consulted on 15 August 2012).

103. "We Stand Up for Faith - A Petition to the National People's Congress Concerning the Conflict between Church and State," 10 May 2011, http://www.chinaaid.org/2011/05/we-stand-up-forour-faith-petition-to.html (consulted on 15 August 2012). On prayer support by more than three dozen churches, see "Beijing jiaomu liandaohui wei beijing shouwang jiaohui daidao" (Beijing Ministerial Prayer Fellowship interceding in prayer for Beijing Shouwang church), 11 May 2011, http://www.chinaaid.net/2011/05/6.html (consulted on 28 August 2012). 
popular group and individual faith, under the protection of the law." (104)

Although the urban churches' efforts to carve out autonomy for religious activity implies destroying the CCP's structures of domination over society, church leaders try to avoid actions that authorities might construe as engaging in politics. Shouwang Church has refused to meet with foreign journalists, because the party-state might cast such interactions as evidence of "foreign enemy" support or at least foreign interference in internal affairs. ${ }^{(105)}$ Yet leaders of well-known urban churches in Beijing and elsewhere enjoy powerful foreign Christian connections. Three of the most prominent church leaders are Korean-Chinese and have travelled to South Korea to discuss their experiences. Several of them also have strong American ties. ${ }^{106)}$ Yet, the urban church pastors shy away from most political acts, preferring to call Christians to submit to ruling authorities by referring to Biblical texts. Despite such precautions, the struggle between Shouwang Church and the authorities prompted a high-level official from the State Administration of Religious Affairs to question an urban church leader with ties to Shouwang "After all, do the [urban] churches oppose the Party?" In the eyes of this official, by seeking to alter registration policies by registering directly with the state (and not under the Protestant associations), urban church leaders are threatening to unravel the entire party-state structure of domination of society, because once churches are granted registration outside corporatist structures, independent workers' unions, political parties, and other groups will soon follow. ${ }^{(107)}$

A second set of urban churches also has the ambition of influencing society, but its leaders take a flexible, conciliatory approach to state interactions reminiscent of the complementary civil society roles played by other religious groups and by the unregistered Wenzhou urban churches described by Nanlai Cao. ${ }^{(108)}$ Their leaders also refuse to register churches out of antipathy to the TSPM/CC, and they also seek to influence society by reaching its elite members. In one central China urban church, a leader said that professors, police, and even government officials participate in her congregation. ${ }^{(109)}$ In the Northeast, a leader set up a worship service in a three-star hotel with a live worship band to attract high-status urbanites who might be put off by the plain surroundings, recorded music, and common people at many unregistered churches. ${ }^{(110)}$

Unlike the more assertive stance of the first group of urban churches, leaders of these churches focus on religious goals alone rather than explicit policy changes. The young north-eastern leader explained that in his interactions with local party-state officials he sought to change their views of unregistered churches as being "out of control" by showing that they actually do not seek to establish an "oppositional church." (111) He therefore deals "respectfully" with officials, as he puts it, even when he is carrying out illegal activities, such as notifying them in advance of a Christmas celebration held in the local Youth Palace. Notification, he took pains to clarify, did not mean asking permission or registering the activity in any way, but when authorities asked that he keep the event a "little quiet," he complied. (112) In similar terms, the central China unregistered church leader emphasised that Protestants need to "look at the whole picture, and see things from [officials'] point of view." (113) Therefore, when authorities requested that his church not hold a service on a particular day, they changed their plans to accommodate the officials because "we can meet on any day." This flexible, yielding approach to dealing with authorities contrasts with the assertive, resolute stance of Shouwang Church and the first set of urban churches.

This second approach aims to make the most of the officials' more relaxed stance toward unregistered Protestant churches by winning their under- standing through mutual respect. "Before we couldn't chat [with officials], only get arrested" for illegal evangelism activities, summarised the northeastern church leader, whereas now his unregistered churches were not targeted by officials for "attack" but rather had gained "tacit approval." (114) Nanlai Cao suggests this state-recognised (but not registered) status partway between legal, official churches under TSPM/CC authority and illegal, unregistered churches is a "third way" to bring churches outside the corporatist structures into the realm of official management. ${ }^{(115)}$

Both types of urban churches seek to transform society through religious activities (and charitable activities), but the first set of open and resolute churches also seeks policy change that draws a clear distinction between state and society in line with a liberal-democratic civil society tradition that differentiates political and religious spheres of action. The second set of open and flexible churches exercises influence primarily by engaging officials through personal relations (guanxi) to further religious goals. Compared to traditional house churches that avoid all official contacts, this engagement suggests that church leaders have softened their perspective on official churches, just as the regime has moderated its treatment of unregistered churches. The north-eastern church leader recognises state interference in official churches, but he no longer labels them "heretical." (116) In fact, he sees decreasing differences between official and unregistered churches and even downplays distinctions between the two types. Further, his nationwide church network no longer seeks to persuade church staff to abandon official churches on account of their "compromised" nature; instead, they are convinced to remain "true" believers so that they can transform official churches from within, even when Protestant association leaders exert pressure to restrict grassroots church work. ${ }^{(117)}$

The new perspective held by urban church leaders also results from the state's own efforts to bring unregistered congregations under Protestant association authority. As the State Administration of Religious Affairs has pushed to register traditional house churches (the latest push in 2010$\left.2012^{(118)}\right)$, churches have affiliated with the weak Protestant associations of some areas and therefore retain considerable autonomy. ${ }^{(19)}$ As one leader explained:

104. Interview, July 2009.

105. Interview, July and August 2010.

106. Shouwang Church's pastor returned from a US sabbatical to lead outdoor protests. Jonathan Bonk, "Pressed but not crushed: The Shouwang Church and OMSC," The Hearth, no. 29, Spring 2011, pp. 1-2, 7.

107. Interview, August 2010

108. Nanlai Cao, Constructing China's Jerusalem, op. cit., p. 27.

109. Interview, September 2010

110. Idem.

111. Interview, August 2010.

112. Idem.

113. Interview, September 2010.

114. Interview, August 2010. Cultivating friendly relations with officials does not mean violating Biblical injunctions, cautioned the central China church leader, who cited verses enjoining Christians to submit to human authorities. Interview, September 2010.

115. Nanlai Cao, Constructing China's Jerusalem, op. cit., p. 27.

116. Interview, August 2010.

117. Idem.

118. "New Campaign to Eradicate House Churches," China Aid website, 20 April 2012, www.chinaaid.org/2012/04/chinaaid-special-report-chinese.html (consulted on 15 August 2012).

119. These churches are what Chinese researchers Duan Qi and Tang Xiaofeng call "independent [Three Self] churches." Duan Qi and Tang Xiaofeng, "2008 nian Zhongguo jidujiao xianzhuang ji yanjiu" (The current situation and study of Chinese Protestantism in the year 2008), art. cit., p. 141. 
I belong to the pure Three Self, approved by the government, but I do everything myself. I don't take any salary, no one is sent [from the party-state] to my church, we preach ourselves, and evangelise on our own. But I'm still Three Self. ${ }^{(120)}$

Such congregations, along with unregistered churches seeking public influence without confrontation, value carrying out religious activities more than they do resisting party-state control over society. Differences have become more blurred between registered official churches that are controlled by associations in the corporatist structures and registered but largely autonomous churches, but these more autonomous churches retain their ambition to influence society (and even state officials) by spreading religious values.

What does this analysis of Protestant Christian churches and their regime interactions tell us about civil society development in China today? First, unlike the most tightly constrained social organisations such as workers' unions, religious organisations of all types have flourished in number as religious membership has skyrocketed to hundreds of millions of adherents, with fewer restrictions than some other types of civil society groups face. (121) Second, and related to the wide diversity of religious groups, they play a range of roles as civil society groups, often complementary to state power, sometimes bolstering regime rule, but rarely undermining it. These roles are partly shaped by the authoritarian political order, which reflects the Chinese Communist Party's continuing ambition to legitimise and dominate public expressions of religion, even if that domination is less (and less often) coercive than before and allows for much organisational manoeuvring by religious leaders to defend particular interests under the carapace of the party-state. The shifting management strategies of the party-state lead to Protestant churches operating on a continuum of state legitimation, from legal registration on one end to "tacit approval" in the middle, all the way to banning on the other end. Taking into account the state's tacit recognition (and the registration of churches under weak associations), it appears that the formal status of church registration may no longer indicate much about the orthodoxy or political loyalty of a congregation in question. Third, as the Protestant population becomes younger, more educated, and wealthier, Protestants are becoming more ambitious, resulting in the emergence of a new type of high-status urban church in major cities nationwide. These churches eschew the small and secretive format of traditional house churches in favour of open meetings, large congregations, and unregistered gatherings aimed at shaping society. Among these high-status urban unregistered churches, leaders of flexible and yielding urban churches exhibit a non-confrontational, "respectful" approach in dealing with party-state cadres, avoid drawing sharp lines, and appear more willing to accept officials' restraints while still reserving room to manoeuvre and continue religious activities in ways not too dissimilar to those of leaders of other religious groups in China. These flexible Protestant leaders suggest that nothing inherent in the Protestant churchstate relationship requires confrontation. At the same time, a resolute, more assertive set of urban church leaders with foreign ties displays characteristics of democratic civil society that may undermine the political order by defending church activities in ways that challenge church registration policies. In so doing, these resolute church leaders implicitly seek to limit state authority over religion and, by extension, over all of society. As in the case of Shouwang Church and other urban churches that hold outdoor worship protests, Protestant groups in China seek to do more than forge "autonomous social spaces" based on Buddhist ethics and charitable giving, as others have noted; (122) they strive to carve out such spaces through public activism that combines religious worship with protest and defends the priority of religion over state domination of society. But unlike Eastern European churches, whose membership encompassed nearly the entire population, whose origins predated Communist Party formations, and whose histories were unencumbered by associations with foreign imperialism, the Chinese Protestant churches' activism cannot challenge the regime's claim to be the bearer of national identity. ${ }^{(123)}$ Instead, their ongoing public worship protests are fuelled by a devoted cadre of church members whose actions rivet international media attention, and constitute a protest against the party-state's public domination of religion and society. Whether their efforts will succeed in a historical division of society from state depends on factors beyond the Protestant churches themselves.

\author{
I Carsten T. Vala is Assistant Professor of Political Science, Loyola \\ University Maryland.
}

4501 N. Charles St., Department of Political Science, Loyola University, Maryland, Baltimore, MD USA 21210 (cvala@loyola.edu).
120. Interview, August 2010.

121. The NGO sector has also flourished, while the All China Federation of Trade Unions has little autonomy and is tightly constrained. See Mary E. Gallagher, "The Limits of Civil Society in a Late Leninist State," art. cit., pp. 429-431.

122. André Laliberté, et al., "Religious Philanthropy and Chinese Civil Society," art. cit., p. 150

123. Maryjane Osa, Solidarity and Contention, op. cit. 